\title{
Habitual intake of dietary L-arginine in relation to risk of type 2 diabetes: a prospective study
}

\author{
Parvin Mirmiran ${ }^{1}$, Zahra Bahadoran ${ }^{*}$, Zahra Gaeini $^{1}$ and Fereidoun Azizi ${ }^{2}$
}

\begin{abstract}
Background: There are insufficient data in case of the potential association of habitual dietary L-arginine and the risk of type 2 diabetes mellitus (T2DM) incidence. Here we aimed to examine the potential effect of dietary Larginine on the T2DM incidence.

Methods: For this cohort study, 2139 T2DM-free adults from the participations of Tehran Lipid and Glucose Study (TLGS) were recruited. Follow up period was approximately 5.8 years. Daily intakes of protein and L-arginine were estimated using a validated food frequency questionnaire with 168 food item. Hazard Ratios (HRs) and 95\% confidence intervals (Cls), adjusted for sex, age, smoking, diabetes risk score, physical activity levels, and total energy intakes as well as carbohydrate, fiber, fats and lysine, were calculated for L-arginine as both absolute intake and its ratio from total protein.

Results: Mean $( \pm S D)$ age of the participants was $38.9( \pm 12.6)$ years and $54.6 \%$ were women. Mean $( \pm S D)$ intake of dietary protein and L-arginine was $77.2( \pm 22.4)$ and $4.05( \pm 1.50) \mathrm{g} / \mathrm{d}$, respectively. An increased risk of T2DM $(H R=$ $2.71,95 \% \mathrm{Cl}=1.20-6.09$ ) was observed among participants with higher intakes of $\mathrm{L}$-arginine (median intake of $>5.4$ vs. $2.69 \mathrm{~g} / \mathrm{d}$ ). Total protein intake and the ratio of L-arginine to total protein intakes were not related to incidence of T2DM in both crude and adjusted models.
\end{abstract}

Conclusion: We found that higher dietary L-arginine levels may increase risk of T2DM and it may have an independent role in T2DM development.

Keywords: L-arginine, Dietary protein, Type 2 diabetes

\section{Background}

L-arginine is a conditionally essential amino acid that involved in the synthesis of proteins, creatine, polyamines, agmatine, urea, and metabolism of proline and glutamate in the body $[1,2]$. The relative amount of L-arginine in different dietary proteins is in a range of $3-15 \%$ [3]; usual daily intakes of the Arg has been estimated to be 4-6 g per day in healthy adults, which provide about

\footnotetext{
* Correspondence: zahrabahadoran@yahoo.com; z.bahadoran@endocrine.ac.ir ${ }^{1}$ Nutrition and Endocrine Research Center, Research Institute for Endocrine Sciences, Shahid Beheshti University of Medical Sciences, P.O. Box: 19395-4763, No. 24, Sahid-Erabi St, Yemen St, Chamran Exp, Tehran, Iran Full list of author information is available at the end of the article
}

$20 \%$ of plasma L-arginine flux [4]. L-arginine has recently received more interest as a nitric oxide (NO) precursor, a property has led to the widespread use of Larginine as a complementary therapy in various NOdisrupted conditions [5, 6].

Short-term beneficial properties of L-arginine supplementation in some pathologic conditions including hypertension, hypertensive renal disease and cardiovascular disease have been investigated [7-9]. Several studies suggested that L-arginine may be involved in multiple NO-dependent pathways that affect the glucose and insulin homeostasis [10, 11]. Beyond its

(c) The Author(s). 2021 Open Access This article is licensed under a Creative Commons Attribution 4.0 International License, which permits use, sharing, adaptation, distribution and reproduction in any medium or format, as long as you give appropriate credit to the original author(s) and the source, provide a link to the Creative Commons licence, and indicate if changes were made. The images or other third party material in this article are included in the article's Creative Commons licence, unless indicated otherwise in a credit line to the material. If material is not included in the article's Creative Commons licence and your intended use is not permitted by statutory regulation or exceeds the permitted use, you will need to obtain permission directly from the copyright holder. To view a copy of this licence, visit http://creativecommons.org/licenses/by/4.0/ The Creative Commons Public Domain Dedication waiver (http://creativecommons.org/publicdomain/zero/1.0/) applies to the data made available in this article, unless otherwise stated in a credit line to the data. 
effects through NO metabolism, L-arginine has direct effect in stimulation of insulin secretion in diabetic rats [12], and it was suggested that L-arginine stimulated glucose-induced insulin secretion in mouse by membrane depolarization, independently of $\mathrm{NO}$, in another observational study [13]. However, due to lack of efficacy and safety of L-arginine supplementation in long-term period (e.g. increased risk of mortality rate and myocardial infarction following 6 months of $9 \mathrm{~g} / \mathrm{d}$ L-arginine supplementation) [14, 15], along with undesired effects of L-arginine (e.g. infusion of arginase activity and increased urea levels), the dominant paradigm about beneficial effects of Larginine is under debate $[16,17]$. In our previous studies we showed that dietary intakes of L-arginine were positively related to NO metabolites levels in serum [18], and increased chance of chronic kidney disease incidence [19], metabolic syndrome [20], and coronary heart disease incidence [21].

Although there are several animal studies investigated the effects of L-arginine supplementation on glucose and insulin homeostasis, long-term effects of L-arginine intake from usual diet in human is unclear. To the best of our knowledge, there is limited data in case of the association of habitual L-arginine intakes from diet and the risk of T2DM, therefore, in this study we aimed to evaluate the possible association of dietary L-arginine, as both absolute intake and its ratio from total protein intake, with the incidence of T2DM in a populationbased study.

\section{Methods}

\section{Study population}

This prospective cohort study was conducted using data collected from the Tehran Lipid and Glucose Study (TLGS). TLGS is an ongoing community-based cohort study, in a sample in the district 13 of Tehran, Iran, aimed to investigate and prevent non-communicable diseases [22]. We recruited 3462 men and women from the participants of the third phase of the TLGS, who had completed dietary and demographic data.

Finally, after exclusion of subjects with T2DM diagnosis at baseline $(n=321)$, participants who had missing data of anthropometrics, biochemical values and physical activity $(n=63)$, and those with under- or over-report of total energy intakes $(<800 \mathrm{kcal} / \mathrm{d}$ or $>4200 \mathrm{kcal} / \mathrm{d})(n=$ 284), 2256 adults were remained and followed up to the fourth and fifth TLGS examinations, $\sim 3$ years apart. Mean period of follow-up was 5.8 years. Final analyses were conducted on 2139 adults (971 men, 1168 women), after exclusion of participants who had no follow-up after the baseline examination $(n=117)$. The flow chart of selection of study population is shown in Fig. 1. The participants with lost to follow-up and missing data were considered as non-responders; accordingly, the response rate of the study was $92.2 \%$.

The study protocol was approved by the ethics research council of the Research Institute for Endocrine Sciences, Shahid Beheshti University of Medical Sciences. Moreover, written informed consents were obtained from all participants.

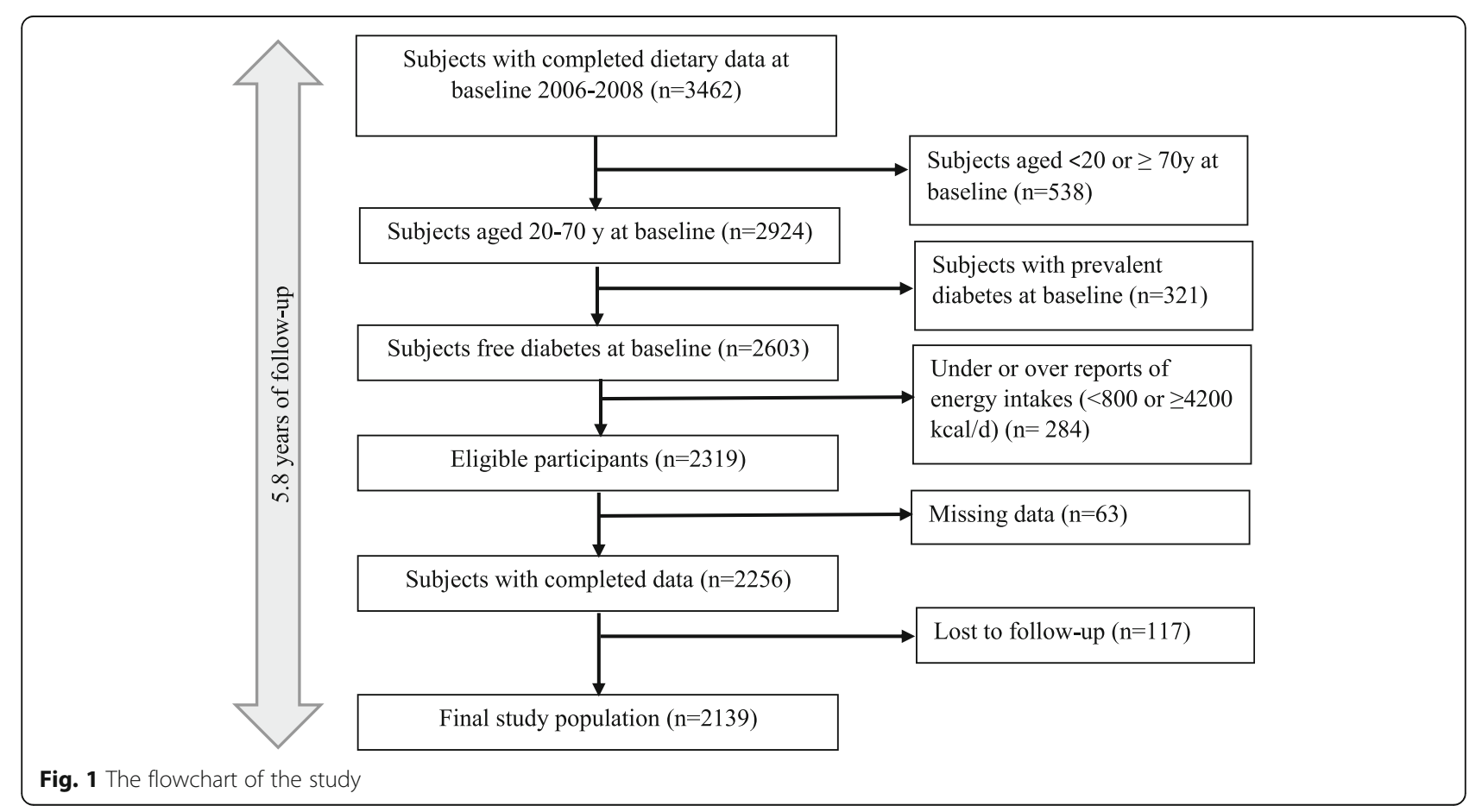




\section{Demographic and anthropometric measures}

Demographic data were conducted by the trained interviewers, using standard questionnaires. Measurements of demographic variables in TLGS have been reported elsewhere in details [22]. Body weight and height of participants were measured using digital scales and a tape meter, to the nearest $100 \mathrm{~g}$ and $0.5 \mathrm{~cm}$, respectively. Subjects were in a standing position, without shoes and minimally clothed for anthropometric measurements. Body mass index (BMI) was calculated as weight $(\mathrm{kg})$ divided by square of the height $\left(\mathrm{m}^{2}\right)$. Furthermore, waist circumference (WC) was measured to the nearest 0.1 $\mathrm{cm}$, over light clothing, between the lower border of the ribs and the iliac crest at the widest portion. WC was measured using a soft measuring tape, with no pressure to the body. Waist to height ratio (WHtR) was calculated as WC divided by height $(\mathrm{cm})$.

To assess both systolic (SBP) and diastolic blood pressure (DBP) of participants, two measurements of blood pressure were taken, with at least a 30-s interval between two measurements. There was a 15-min rest before blood pressure measurements, and subjects were in the sitting position. For this purpose, we used a standardized mercury sphygmomanometer calibrated by the Iranian Institute of Standard and Industrial Research. Final blood pressure of participants was considered as the mean of the two measurements.

To assess physical activity level of participants, the frequency and time spent on light, moderate, high and very high intensity activities, according to the list for common activities of daily life were asked over the past year. We used metabolic equivalent hours per week (METs h/ week) to express physical activity levels.

\section{Biochemical measures}

Participants had a $12-14 \mathrm{~h}$ of overnight fasting before biochemical measurements. Blood samples were drawn between 7:00 and 9:00 AM. Fasting serum glucose (FSG) and serum triglyceride (TG) were assayed using glucose oxidase and glycerol phosphate oxidase, respectively. The method used to measure FSG and TG was enzymatic colorimetric. High-density lipoprotein cholesterol (HDL-C) was measured after precipitation of the apolipoprotein B containing lipoproteins with phosphotungstic acid. Analyses were performed using Pars Azmoon kits (Pars Azmoon Inc., Tehran, Iran) and a Selectra 2 auto-analyzer (Vital Scientific, Spankeren, Netherlands). Both inter- and intra-assay coefficients of variation of all assays were $<5 \%$.

\section{Dietary assessment}

Typical food intakes were assessed using a validated 168-item FFQ. The validity and reliability of the questionnaire have been previously evaluated [23]. The intake frequencies for each food item during the past year were asked on a daily, weekly, or monthly basis. Then we converted the reported portion sizes in household measures to grams [24]. To analyze the energy and nutrient contents of foods and beverages, we used the US Department of Agriculture Food Composition Table, because the Iranian Food Composition Table is incomplete, and has limited data [25]. To obtain dietary total intake of L-arginine, the L-arginine content of food items (mg/100 g of foods) were multiplied by the amount of daily intake of food items, then the obtained values were summed up [18].

\section{Definition of terms}

A T2DM patient considered as a subject who met at least one of the following criteria: (1) using anti-diabetic drugs, (2) fasting serum glucose (FSG) $\geq 126 \mathrm{mg} / \mathrm{dL}$, (3) 2 -h post challenging glucose (2-hPCG) $\geq 200 \mathrm{mg} / \mathrm{dL}$ [26]. If they had at least one parent or sibling with T2DM, a positive family history of diabetes was considered for them. To calculate the diabetes risk score (DRS), we summed up the points considered for each following items: SBP (mm Hg) $<120$ (0 point), $120<$ SBP $<140$ (3 point), $\mathrm{SBP} \geq 140$ (7 point); waist to height ratio (WHtR): $<0.54$ (0 point), $0.54-0.59$ (6 point), $\geq 0.59$ (11 point); family history of diabetes ( 5 point); FSG ( $\mathrm{mmol} / \mathrm{L}):<5$ (0 point), $50-5.5$ (12 point), 5.6-6.9 (33 point); TG/ HDL-C: $<3.5$ (0 point), $\geq 3.5$ (3 point) [27].

\section{Statistical analysis}

Mean and standard deviation (SD) values, and the frequency (\%) of baseline characteristics were compared across tertiles of L-arginine intakes, using independent analysis of variance or chi square test, respectively. Hazard ratios (HRs) and 95\% confidence intervals (CIs) for the association between $\mathrm{L}$-arginine intakes and Larginine to protein ratio in relation to incidence of T2DM were estimated using Cox proportional hazards regression models with person-year as the underlying time metric. Cox models were adjusted for sex, age, smoking, diabetes risk score, physical activity levels, and total energy intakes as well as dietary carbohydrate, fiber, fats and lysine.

The middle-time between the date of the first diagnosis of T2DM, and the most recent follow-up visit preceding the diagnosis were considered as the event date for T2DM cases. The difference between the calculated middle-time date and the date at which the subjects entered the study was considered as the follow-up time. In case of the censored and lost to follow-up subjects, the survival time was the interval between the first and the last observation dates. Follow-up duration and personyears were calculated using the measured survival time. 
All analyses were performed using IBM SPSS for Windows version 20 , with a two-tailed $P$ value $<0.05$ being considered significant.

\section{Results}

Mean (SD) age of the participants was 38.9 (12.6) years and $45.4 \%$ were men. Mean (SD) BMI was $26.9(4.7) \mathrm{kg} /$ $\mathrm{m}^{2}$ at baseline. A total of 143 cases of T2DM were identified over a median 5.8 years of follow-up. Mean (SD) intake of dietary protein and L-arginine was 77.2 (22.4) and $4.05(1.50) \mathrm{g} / \mathrm{d}$, respectively. There were no significant differences between dietary intakes of L-arginine, total protein and L-arginine/protein ratio in subjects with or without T2DM $(4.05 \pm 1.5 \mathrm{~g} / \mathrm{d}$ vs. $4.05 \pm 1.51 \mathrm{~g} / \mathrm{d}$, $75.91 \pm 25.95 \mathrm{~g} / \mathrm{d}$ vs. $77.39 \pm 27.56 \mathrm{~g} / \mathrm{d}, 0.053 \pm 0.006$ vs. $0.053 \pm 0.006$, respectively).

Baseline characteristics of participants are shown in Table 1. Participants in the highest compared to the lowest intake of L-arginine were more likely to be younger ( 38.5 vs. 40.6 years, $P=0.006$ ), and had higher physical activity ( 36.8 vs. $30.4 \mathrm{MET}$-h/week, $P=0.08$ ). There was no statistically significant difference in anthropometric and biochemical values as well as diabetes risk score across dietary intakes of L-arginine. Dietary intake of carbohydrate, fiber and protein was significantly increased with higher intakes of L-arginine, whereas intakes of total fat decreased $(P$ for all $<0.01)$.
Association between L-arginine intakes as well as dietary protein and L-arginine to protein ratio with the incidence of T2DM after a 5.8 y of follow-up are shown in Table 2. In the crude model, there was no statistically significant association between intakes of L-arginine and risk of T2DM $(\mathrm{HR}=0.83,95 \% \mathrm{CI}=0.55-1.26$, and $\mathrm{HR}=$ $1.06,95 \% \mathrm{CI}=0.71-1.56$, in the second and third tertile, respectively). After adjustment of diabetes risk score, physical activity, sex, age, smoking, total energy intakes, and carbohydrates, fiber, fats, lysine and total protein intakes, the risk of T2DM significantly increased in the highest tertile compared to the lowest tertile categories of L-arginine intakes ( $\mathrm{HR}=2.71,95 \% \mathrm{CI}=1.20-6.09)$. Total protein and the ratio of L-arginine to total protein intake were not significantly associated with risk of T2DM $(\mathrm{HR}=1.89,95 \% \mathrm{CI}=0.99-3.60)$, in both crude and adjusted models. It is notable that there was no sex interaction between $\mathrm{L}$-arginine and T2DM in our study.

\section{Discussion}

In the current prospective population-based study, we showed a potential adverse effect of high L-arginine intakes (more than $5.4 \mathrm{~g} / \mathrm{d}$ ) from habitual diet in relation to risk of T2DM, during 5.8 years of follow-up. Higher intakes of L-arginine however were not a potential risk for development of T2DM when it was considered in the context of total protein intake, as L-arginine-to-protein ratio.

Table 1 Characteristics of the study population across tertiles of dietary L-arginine intakes

\begin{tabular}{|c|c|c|c|c|}
\hline & \multicolumn{4}{|c|}{ Dietary L-arginine } \\
\hline & Tertile 1 & Tertile 2 & Tertile 3 & $P^{*}$ \\
\hline \multicolumn{5}{|l|}{ L-arginine $(g / d)$} \\
\hline Range & $<3.31$ & $3.31-4.45$ & $>4.45$ & \\
\hline Median & 2.69 & 3.77 & 5.40 & \\
\hline Age (y) & $40.6 \pm 12.8$ & $39.4 \pm 12.3$ & $38.5 \pm 12.6$ & 0.006 \\
\hline Men (\%) & 35.1 & 45.6 & 55.5 & 0.001 \\
\hline Current smoker (\%) & 10.2 & 14.2 & 12.5 & 0.011 \\
\hline Physical activity (MET-h/week) & $30.4 \pm 45.0$ & $33.7 \pm 52.0$ & $36.8 \pm 57.0$ & 0.086 \\
\hline BMI $\left(\mathrm{kg} / \mathrm{m}^{2}\right)$ & $27.0 \pm 4.8$ & $26.8 \pm 4.7$ & $27.1 \pm 4.7$ & 0.448 \\
\hline FSG $(m m o / / L)$ & $4.81 \pm 0.47$ & $4.80 \pm 0.44$ & $4.84 \pm 0.47$ & 0.186 \\
\hline 2-hPCG (mmol/L) & $5.36 \pm 1.41$ & $5.21 \pm 1.31$ & $5.28 \pm 1.37$ & 0.098 \\
\hline TG to HDL-C ratio & $1.66 \pm 0.2$ & $1.65 \pm 0.2$ & $1.68 \pm 0.2$ & 0.680 \\
\hline Diabetes risk score & $9.3 \pm 10.0$ & $9.1 \pm 10.0$ & $9.7 \pm 10.1$ & 0.564 \\
\hline \multicolumn{5}{|l|}{ Dietary intakes } \\
\hline Carbohydrate (\% of energy) & $57.0 \pm 7.5$ & $57.7 \pm 6.5$ & $58.1 \pm 7.4$ & 0.030 \\
\hline Fat (\% of energy) & $32.4 \pm 7.5$ & $31.3 \pm 6.6$ & $29.9 \pm 6.6$ & 0.001 \\
\hline Protein (\% of energy) & $12.9 \pm 2.2$ & $13.6 \pm 3.1$ & $14.5 \pm 2.6$ & 0.001 \\
\hline Total fiber ( $g / 1000 \mathrm{kcal})$ & $15.9 \pm 6.9$ & $16.5 \pm 3.4$ & $17.0 \pm 6.8$ & 0.001 \\
\hline L-arginine to protein ratio & $0.051 \pm 0.01$ & $0.052 \pm 0.01$ & $0.054 \pm 0.01$ & 0.001 \\
\hline
\end{tabular}

Data are mean \pm SD unless stated otherwise (Analysis of variance and chi-square test was used for continuous and dichotomous variables, respectively) 
Table 2 The risk of type 2 diabetes across tertile categories of dietary L-arginine, dietary protein and L-arginine to protein ratio

\begin{tabular}{ccccc}
\hline & \multicolumn{3}{c}{ Hazard Ratio (95\% Cl) } & \\
\cline { 2 - 5 } & $\boldsymbol{T}_{\mathbf{1}}$ & $\boldsymbol{T}_{\mathbf{2}}$ & $\boldsymbol{T}_{\mathbf{3}}$ & ${\boldsymbol{P} \text { for } \text { trend }^{*}}^{*}$ \\
\hline L-arginine & & & & \\
Crude & Ref. & $0.83(0.55-1.26)$ & $1.06(0.71-1.56)$ & 0.430 \\
Model 1 & Ref. & $1.00(0.65-1.54)$ & $0.95(0.62-1.45)$ & 0.816 \\
Model 2 & Ref. & $1.44(0.84-2.46)$ & $2.72(1.21-6.08)$ & 0.019 \\
Model 3 & Ref. & $1.44(0.84-2.47)$ & $2.71(1.20-6.09)$ & 0.020 \\
Total protein & & & & \\
Crude & Ref. & $0.90(0.60-1.35)$ & $0.94(0.63-1.40)$ & 0.494 \\
Model 1 & Ref. & $1.33(0.83-2.12)$ & $1.46(0.94-2.27)$ & 0.099 \\
Model 2 & Ref. & $1.42(0.84-2.39)$ & $1.89(0.99-3.60)$ & 0.052 \\
L-arginine to protein ratio & & \\
Crude & Ref. & $1.07(0.70-1.64)$ & $1.45(0.97-2.16)$ & 0.145 \\
Model 1 & Ref. & $1.02(0.64-1.61)$ & $1.28(0.84-1.95)$ & 0.242 \\
Model 2 & Ref. & $0.93(0.58-1.50)$ & $1.22(0.78-1.90)$ & 0.371 \\
\hline
\end{tabular}

Hazard ratio and $95 \%$ confidence interval; Cox regression models were used Model 1: Adjusted for sex, age, smoking, diabetes risk score and physical activity

Model 2: additional adjustment for total energy intakes, dietary carbohydrate, fiber, fat and lysine

Model 3: additional adjustment for total protein intake

$P$ for trend test was performed by considering each ordinal score variable as a continuous variable in the model

Mean dietary intake of L-arginine was $4.0 \pm 1.5 \mathrm{~g} / \mathrm{d}$ in our population, with major dietary sources of grains and meats. Although there is no recommended dietary allowance for L-arginine [4], mean dietary intake of Larginine has been reported $4-6 \mathrm{~g} / \mathrm{d}$ in different population $[28,29]$. Different dietary sources have $3-15 \%$ of Larginine, with highest amount of L-arginine for soy protein, peanuts, walnuts, and fish; whereas cereal proteins are poor sources of $\mathrm{L}$-arginine $(3-4 \%$ of total amino acids) [30]. Different dietary patterns among population are responsible for a wide range of dietary intakes and plasma concentrations of L-arginine worldwide [21,30].

Limited data are available regarding the possible association of dietary L-arginine and the cardio-metabolic outcomes. Low intakes of $\mathrm{L}$-arginine (below the median range of $3.8 \mathrm{~g} / \mathrm{d}$ ) has been reported to be associated with the higher $C$ reactive protein (CRP) levels, while the highest level of L-arginine intake $(>7.5 \mathrm{~g} / \mathrm{d})$ increased risk of high-CRP levels by 30\% [29]. Also, higher dietary intakes of L-arginine was associated with significantly higher risk of coronary heart disease (CHD) incidence (relative risk $=1.87,95 \% \mathrm{CI}=1.06-3.29$ for intakes of $\mathrm{L}$ arginine in a range of 3.86-4.65) [31]. L-arginine intake from animal sources was also related to higher diastolic blood pressure and increased risk of CHD events (hazard ratio $=1.90,95 \% \mathrm{CI}=1.03-3.58$ ) [21]. In our previous study, participants with higher intakes of L-arginine from animal sources had significantly higher risk for metabolic syndrome incidence (odd ratios $=1.49,9595 \%$ $\mathrm{CI}=1.02-2.18)$ [20]. Similarly, subjects with the highest amount of dietary animal-derived L-arginine, compared to whom with the lowest intakes $(2.57$ vs. $1.05 \mathrm{~g} / \mathrm{d})$ had significantly increased risk of chronic kidney disease (relative risk $=1.54 ; 95 \% \mathrm{CI}=1.06-2.14$ ); L-arginine intakes from animal sources were also associated with decreased estimated glomerular filtration rate and creatinine clearance rate [19].

Patients with T2DM had higher plasma L-arginine concentration $\quad($ median $=9.74$, inter-quartile range $=$ $5.33-16.61$ vs. median $=4.47$, inter-quartile range $=$ 3.07-6.70); L-arginine concentration was positively associated with T2DM (odds ratio $=1.20,1.17-1.23$ ) [32]. A 10-year follow-up study also indicated that high levels of L-arginine significantly increased risk of T2DM by $21 \%$ (hazard ratio $=1.21,95 \% \mathrm{CI}=1.07-1.37$ ) [33]. A metaanalysis demonstrated that plasma L-arginine concentration is positively related to elevated risk of T2DM (pooled estimated relative risk $=1.19,95 \% \mathrm{CI}=1.14$ 1.25) [34].

The biological plausible mechanisms linking L-arginine intake to risk of T2DM are not well documented. One possible explanation may be related to induction of arginase activity by long-term high intakes of L-arginine $[2,17]$, that has been suggested may contribute to the development of T2DM and insulin resistance [35]. The elevated levels of Larginine is suggested to increase urea synthesis, because Larginine induces $\mathrm{N}$-acetylglutamate synthase which further activates carbamoyl phosphate synthetase-I (CPS-I) to start urea cycle [32]. L-arginine may also decrease cellular uptake of citrulline [36], interrupt recycling of L-arginine form citrulline [17], and suppress endothelial NO synthase (eNOS) expression and activity [37], resulting decreased eNOSderived NO and development of insulin resistance. On the other hand, high-L-arginine intakes is suggested to be related with pathologic levels of NO metabolites [38-40], possibly produced by inducible NO synthase (iNOS); higher intakes of L-arginine were associated with higher serum NO metabolites [18, 20], an independent risk factor of cardio-metabolic diseases [38, 40, 41].

Further prospective studies are needed to more fully determine the possible underlying mechanisms by which high intakes of L-arginine increased risk of T2DM.

The population-based prospective setting of the current study, and use of a validated FFQ to assess regular dietary intake are the main strength points of the study. Due to low number of outcomes $(n=143)$, we used the DRS in multivariate models, which allowed us to not adding many variables that would lead to instability of our models, and accounts for major T2DM confounders. However it had some limitations. First, we had not data on serum levels of L-arginine to consider in our analysis; however, an acceptable correlation was 
observed between dietary L-arginine intakes and serum $\mathrm{L}$-arginine. Some inherent limitation points of observational studies including potential selection bias, information bias in measuring L-arginine intakes as study exposure, and non-differential misclassification of the exposure also should be considered. Furthermore, there are other potential confounding variables, including some dietary factors, which could affect the association of L-arginine and T2DM and were not included in our adjusted models; since L-arginine is derived from different food sources, other dietary factors occurring in the same foods could also have affected the findings. Other potential limitation of the present study is the possible changes of dietary patterns during the follow-up period, since we assessed the dietary information only at baseline examinations; however previous observations in our population indicates an acceptable stability of major dietary patterns over the time.

\section{Conclusion}

Our findings from this prospective study indicated that higher amount of dietary L-arginine may be potential risk factor for development of T2DM. Considering the increasing interest to ingestion of L-arginine as a popular dietary supplement, and also the limited data in case of the potential association between dietary L-arginine and cardio-metabolic outcomes especially T2DM, further cohort studies are required to clarify the possible association.

\section{Abbreviations \\ BMl: Body Mass Index; Cl: Confidence Intervals; CHD: Coronary Heart Disease; C-RP: C - reactive protein; DBP: Diastolic Blood Pressure; DRS: Diabetes Risk Score; FSG: Fasting Serum Glucose; FFQ: Food Frequency Questionnaire; HDL-C: High-Density Lipoprotein Cholesterol; HR: Hazard Ratios; LDL-C: Low- Density Lipoprotein Cholesterol; MET: Metabolic Equivalent; NO: Nitric Oxide; SBP: Systolic Blood Pressure; TLGS: Tehran Lipid and Glucose Study; \\ T2D: Type 2 Diabetes; TG: Triglyceride; WC: Waist Circumference; WHtR: Waist to Height Ratio; 2-hPCG: 2-h Post Challenging Glucose}

\section{Acknowledgements}

We thank the Tehran Lipid and Glucose Study participants and the field investigators of the Tehran Lipid and Glucose Study for their cooperation and assistance in physical examinations, biochemical evaluation and database management.

\section{Authors' contributions}

P.M designed the study. Z. G, Z.B and F. A analyzed the data from TLGS population, Z. B and P. M wrote the manuscript, Z. G corrected the manuscript. All authors read and approved the final manuscript.

\section{Funding}

This work was not supported by any funding agency.

\section{Availability of data and materials}

The datasets used and/or analyzed during the current study available from the corresponding author on reasonable request.

\section{Declarations}

\section{Ethics approval and consent to participate}

The study protocol was approved (ethics committee number: 57ECRIES94/ 02/15) by the ethics research council of the Research Institute for Endocrine Sciences, Shahid Beheshti University of Medical Sciences. Written informed consents were obtained from all participants. The study protocol was conducted according to the principles expressed in the Declaration of Helsinki.

\section{Consent for publication}

Not Applicable.

\section{Competing interests}

The authors declare that they have no competing of interests. Dr. Zahra Bahadoran is a member of the editorial board of BMC Endocrine Disorders.

\section{Author details \\ ${ }^{1}$ Nutrition and Endocrine Research Center, Research Institute for Endocrine Sciences, Shahid Beheshti University of Medical Sciences, P.O. Box: 19395-4763, No. 24, Sahid-Erabi St, Yemen St, Chamran Exp, Tehran, Iran. ${ }^{2}$ Endocrine Research Center, Research Institute for Endocrine Sciences, Shahid Beheshti University of Medical Sciences, Tehran, Iran.}

Received: 25 July 2020 Accepted: 20 May 2021

Published online: 31 May 2021

\section{References}

1. Morris SM Jr. Arginine metabolism: boundaries of our knowledge. J Nutr. 2007;137(6):1602S-9S. https://doi.org/10.1093/jn/137.6.1602S

2. Wu G, Morris SM, Jr. Arginine metabolism: nitric oxide and beyond. Biochem J. 1998;336 (Pt 1):1-17.

3. Lüneburg N, Xanthakis V, Schwedhelm E, Sullivan LM, Maas R, Anderssohn $M$, et al. Reference intervals for plasma $L$-arginine and the $L$-arginine: asymmetric dimethylarginine ratio in the Framingham offspring cohort. J Nutr. 2011;141(12):2186-90. https://doi.org/10.3945/jn.111.148197.

4. Luiking YC, Castillo L, Deutz NE. Arginine, citrulline, and nitric oxide. Modern Nutrition in Health and Disease: Eleventh Edition: Wolters Kluwer Health Adis (ESP); 2012. p. 477-86.

5. Kohli R, Meininger CJ, Haynes TE, Yan W, Self JT, Wu G. Dietary L-arginine supplementation enhances endothelial nitric oxide synthesis in streptozotocin-induced diabetic rats. J Nutr. 2004;134(3):600-8. https://doi. org/10.1093/jn/134.3.600.

6. Wu G, Collins JK, Perkins-Veazie P, Siddiq M, Dolan KD, Kelly KA, et al. Dietary supplementation with watermelon pomace juice enhances arginine availability and ameliorates the metabolic syndrome in Zucker diabetic fatty rats. J Nutr. 2007;137(12):2680-5. https://doi.org/10.1093/jn/137.12.2680.

7. Dong JY, Qin LQ, Zhang Z, Zhao Y, Wang J, Arigoni F, et al. Effect of oral L-arginine supplementation on blood pressure: a meta-analysis of randomized, double-blind, placebo-controlled trials. Am Heart J. 2011;162(6): 959-65. https://doi.org/10.1016/j.ahj.2011.09.012.

8. McRae MP. Therapeutic benefits of I-arginine: an umbrella review of metaanalyses. J Chiropractic Med. 2016;15(3):184-9. https://doi.org/10.1016/j. jcm.2016.06.002.

9. Fisman EZ, Tenenbaum A, Shapira I, Pines A, Motro M. The nitric oxide pathway: is L-arginine a gate to the new millennium medicine? A metaanalysis of L-arginine effects. J Med. 1999;30(3-4):131-48.

10. Jobgen WS, Fried SK, Fu WJ, Meininger CJ, Wu G. Regulatory role for the arginine-nitric oxide pathway in metabolism of energy substrates. J Nutr Biochem. 2006;17(9):571-88. https://doi.org/10.1016/j.jnutbio.2005.12.001.

11. Wu G, Bazer FW, Davis TA, Kim SW, Li P, Rhoads JM, et al. Arginine metabolism and nutrition in growth, health and disease. Amino Acids. 2009; 37(1):153-68. https://doi.org/10.1007/s00726-008-0210-y.

12. Adeghate EPA, El-Sharkawy T, Parvez H. L-arginine stimulates insulin secretion from the pancreas of normal and diabetic rats. Amino Acids. 2001; 21(2):205-9. https://doi.org/10.1007/s007260170028.

13. Thams P, Capito K. L-arginine stimulation of glucose-induced insulin secretion through membrane depolarization and independent of nitric oxide. Eur J Endocrinol. 1999;140(1):87-93. https://doi.org/10.1530/eje.0.14 00087. 
14. Walker HA, McGing E, Fisher I, Böger RH, Bode-Böger SM, Jackson G, et al. Endothelium-dependent vasodilation is independent of the plasma L-arginine/ ADMA ratio in men with stable angina: lack of effect of oral l-arginine on endothelial function, oxidative stress and exercise performance. J Am Coll Cardiol. 2001;38(2):499-505. https://doi.org/10.1016/S0735-1097(01)01380-8.

15. Schulman SP, Becker LC, Kass DA, Champion HC, Terrin ML, Forman S, et al. L-arginine therapy in acute myocardial infarction: the vascular interaction with age in myocardial infarction (VINTAGE MI) randomized clinical trial. Jama. 2006;295(1):58-64. https://doi.org/10.1001/jama.295.1.58.

16. Morris SM Jr. Regulation of enzymes of urea and arginine synthesis. Annu Rev Nutr. 1992;12(1):81-101. https://doi.org/10.1146/annurev.nu.12.070192. 000501.

17. Cynober L, Le Boucher J, Vasson M-P. Arginine metabolism in mammals. J Nutr Biochem. 1995;6(8):402-13. https://doi.org/10.1016/0955-2863 (95)00066-9.

18. Mirmiran P, Bahadoran Z, Ghasemi A, Azizi F. The Association of Dietary LArginine Intake and Serum Nitric Oxide Metabolites in Adults: A PopulationBased Study. Nutrients. 2016;8(5):311-23.

19. Bahadoran Z, Mirmiran P, Golzarand M, Davudabadi-Farahani R, Azizi F. Dietary animal-derived L-arginine intakes and risk of chronic kidney disease: a 6-year follow-up of Tehran lipid and glucose study. Iran J Kidney Dis. 2017;11(5):352-9.

20. Mirmiran P, Moghadam SK, Bahadoran Z, Ghasemi A, Azizi F. Dietary L arginine intakes and the risk of metabolic syndrome: a 6-year follow-up in Tehran lipid and glucose study. Preventive Nutri Food Sci. 2017;22(4):26370. https://doi.org/10.3746/pnf.2017.22.4.263.

21. Bahadoran Z, Mirmiran P, Tahmasebinejad Z, Azizi F. Dietary L-arginine intake and the incidence of coronary heart disease: Tehran lipid and glucose study. Nutr Metab (Lond). 2016;13:23.

22. Azizi F, Ghanbarian A, Momenan AA, Hadaegh F, Mirmiran P, Hedayati M, et al. Prevention of non-communicable disease in a population in nutrition transition: Tehran lipid and glucose study phase II. Trials. 2009;10(1):1-15.

23. Mirmiran P, Esfahani FH, Mehrabi Y, Hedayati M, Azizi F. Reliability and relative validity of an FFQ for nutrients in the Tehran lipid and glucose study. Public Health Nutr. 2010;13(5):654-62. https://doi.org/10.1017/S13 68980009991698.

24. Hosseini-Esfahani F, Jessri M, Mirmiran P, Bastan S, Azizi F. Adherence to dietary recommendations and risk of metabolic syndrome: Tehran lipid and glucose study. Metabolism. 2010;59(12):1833-42. https://doi.org/10.1016/j. metabol.2010.06.013.

25. Mirvish SS. Blocking the formation of N-nitroso compounds with ascorbic acid in vitro and in vivo. Ann N Y Acad Sci. 1975;258(1):175-80. https://doi. org/10.1111/j.1749-6632.1975.tb29277.x.

26. Standards of medical care in diabetes--2014. Diabetes Care. 2014;37 Suppl 1: S14-80. https://care.diabetesjournals.org/content/37/Supplement_1/S14.

27. Bozorgmanesh M, Hadaegh F, Ghaffari S, Harati H, Azizi F. A simple risk score effectively predicted type 2 diabetes in Iranian adult population: population-based cohort study. Eur J Pub Health. 2011;21(5):554-9. https:// doi.org/10.1093/eurpub/ckq074.

28. King DE, Mainous AG. 3rd, Geesey ME. Variation in L-arginine intake follow demographics and lifestyle factors that may impact cardiovascular disease risk. Nutr Res. 2008;28(1):21-4. https://doi.org/10.1016/j.nutres.2007.11.003.

29. Wells BJ, Mainous AG 3rd, Everett CJ. Association between dietary arginine and C-reactive protein. Nutrition. 2005;21(2):125-30. https://doi.org/10.1016/ j.nut.2004.03.021.

30. Boger RH. The pharmacodynamics of L-arginine. J Nutr. 2007;137(6 Suppl 2): 1650S-5S. https://doi.org/10.1093/jn/137.6.1650S.

31. Oomen CM, van Erk MJ, Feskens EJ, Kok FJ, Kromhout D. Arginine intake and risk of coronary heart disease mortality in elderly men. Arterioscler Thromb Vasc Biol. 2000;20(9):2134-9. https://doi.org/10.1161/01.ATV.20. 9.2134.

32. Cao Y-F, Li J, Zhang Z, Liu J, Sun X-Y, Feng X-F, et al. Plasma Levels of Amino Acids Related to Urea Cycle and Risk of Type 2 Diabetes Mellitus in Chinese Adults. Front Endocrinol (Lausanne). 2019;10:50.

33. McCann A, Melvaer Giil L, Ulvik A, Seifert R, Rebnord EW, Pedersen ER, et al. Plasma amino acids and incident type 2 diabetes in patients with coronary artery disease. Diabetes Care. 2019;42(7):1225-33. https://doi.org/10.2337/ dc18-2217.

34. Guasch-Ferré M, Hruby A, Toledo E, Clish CB, Martínez-González MA, SalasSalvadó J. Metabolomics in Prediabetes and Diabetes: A Systematic Review and Meta-analysis. 2016;39(5):833-46. https://doi.org/10.2337/dc15-2251.
35. Kashyap SR, Lara A, Zhang R, Park YM, DeFronzo RA. Insulin reduces plasma Arginase activity in type 2 diabetic patients. Diabetes Care. 2008;31(1):134-9. https://doi.org/10.2337/dc07-1198.

36. Bahri S, Curis E, El Wafi F-Z, Aussel C, Chaumeil J-C, Cynober L, et al. Mechanisms and kinetics of citrulline uptake in a model of human intestinal epithelial cells. Clin Nutr. 2008;27(6):872-80. https://doi.org/10.1016/j.clnu.2 008.08.003.

37. Mohan S, Wu CC, Shin S, Fung HL. Continuous exposure to L-arginine induces oxidative stress and physiological tolerance in cultured human endothelial cells. Amino Acids. 2012;43(3):1179-88. https://doi.org/10.1007/ s00726-011-1173-y.

38. Ghasemi A, Zahediasl S, Azizi F. High serum nitric oxide metabolites and incident metabolic syndrome. Scand J Clin Lab Invest. 2012;72(7):523-30. https://doi.org/10.3109/00365513.2012.701322.

39. Hadaegh F, Asgari S, Bozorgmanesh M, Jeddi S, Azizi F, Ghasemi A. Added value of total serum nitrate/nitrite for prediction of cardiovascular disease in middle east caucasian residents in Tehran. Nitric Oxide. 2016;54:60-6. https://doi.org/10.1016/j.niox.2016.02.004.

40. Bahadoran Z, Mirmiran P, Ghasemi A, Azizi F. Serum nitric oxide metabolites are associated with the risk of hypertriglyceridemic-waist phenotype in women: Tehran lipid and glucose study. Nitric Oxide. 2015;50:52-7. https:// doi.org/10.1016/j.niox.2015.08.002.

41. Bahadoran Z, Mirmiran P, Tahmasebi Nejad Z, Ghasemi A, Azizi F. Serum nitric oxide is associated with the risk of chronic kidney disease in women: Tehran lipid and glucose study. Scand J Clin Lab Invest. 2016;76(4):304-8.

\section{Publisher's Note}

Springer Nature remains neutral with regard to jurisdictional claims in published maps and institutional affiliations.
Ready to submit your research? Choose BMC and benefit from:

- fast, convenient online submission

- thorough peer review by experienced researchers in your field

- rapid publication on acceptance

- support for research data, including large and complex data types

- gold Open Access which fosters wider collaboration and increased citations

- maximum visibility for your research: over $100 \mathrm{M}$ website views per year

At BMC, research is always in progress.

Learn more biomedcentral.com/submissions 